\title{
Pengembangan Kapasitas Aparatur Pemerintah Desa Di Desa Aek Korsik
}

\section{Capacity Development of Village Government Apparatus in Aek Korsik Village}

\author{
Mahdalena Manalu1)*, Husni Thamrin Nasution1) \& Irwan Nasution ${ }^{2)}$ \\ 1) Program Studi Administrasi Publik, Fakultas Ilmu Sosial dan Ilmu Politik \\ Universitas Medan Area, Indonesia \\ 2) Program Studi Administrasi Publik, Fakultas Ilmu Sosial dan Ilmu Politik \\ Universitas Medan Area, Indonesia
}

Diterima: Mei 2019; Disetujui: Juni 2019; Dipublish: Juni 2019

\begin{abstract}
Abstrak
Penelitian ini berfokus pada Pengembangan Kapasitas Aparatur Pemerintah Desa, Studi Kasus Desa Aek Korsik kecamatan Aek Kuo, Sifat Penelitian ini adalah Deskriptif. Hasil Penelitian menunjukkan bahwa Kemampuan para Aparatur Pemerintah Desa Aek Korsik Kecamatan Aek Kuo Kabupaten Labuhan Batu Utara belum maksimal, sehingga berdampak kepada seluruh kinerja para Aparatur Pemerintah Desa. Dalam penelitian ini, peneliti menemukan bahwa dalam Pengembangan Kapasitas Aparatur Pemerintah Desa Aek korsik menggunakan metode on the job yaitu melalui magang maupun bimbingan, serta menggunakan metode off the job yang di lakukan dengan mengikutsertakan para pegawai dalam hal diklat dan pendidikan lainnya yang disediakan oleh Pemerintah. Dan saya berharap dengan adanya pelatihan yang di berikan mampu lebih meningkatkan kompetensi para aparatur desa.
\end{abstract}

Kata Kunci: Manajemen Sumber Daya Manusia, Pendidikan dan Pelatihan, Kompetensi Pegawai, Kualitas Pelayanan

\begin{abstract}
This research focuses on Capacity Building of Village Government Apparatus, Case Study of AekKorsik Village, AekKuo sub-district, the nature of this research is Descriptive. The results showed that the ability of the AekKorsik Village Government Apparatus in AekKuo District, North LabuhanBatu District had not been maximized, thus impacting the overall performance of the Village Government Apparatus. In this study, researchers found that in the Capacity Development of AekKorsik Village Government Apparatus using the on the job method through internships and mentoring, and using the off the job method that is done by involving employees in the education and other education provided by the Government. And I hope that the training provided will be able to further improve the competence of village officials.
\end{abstract}

Keywords: Human Resource Management, Education and Training, Employee Competence, Service Quality

How to Cite: Manalu, M. Nasution, H.T. Nasution, I. (2018). Pengembangan Kapasitas Aparatur Pemerintah Desa Di Desa Aek Korsik Kecamatan Aek Kuo Kabupaten Labuhan Batu Utara, PERSPEKTIF, 7 (2): 55-59.

${ }^{*}$ Corresponding author:

ISSN 2085-0328 (Print)

E-mail:mahdalena.manalu165@gmail.com 


\section{PENDAHULUAN}

Undang-Undang No. 6 Tahun 2014 Tentang Desa merupakan kebijakan penting dan fundamental dalam tata kelola pemerintahan desa. Salah satu keputusan strategis yang dibuat oleh pemerintah dan Dewan Perwakilan Rakyat adalah ditetapkannya Alokasi Dana Desa dalam rangka pelaksanaan hak dan kewajiban desa. Namun demikian seiring dengan terobosan besar melalui implementasi undang-undang desa, pemerintah juga memiliki pekerjaan rumah yang tidak ringan mengingat potensi persoalan dan kegagalan yang ditimbulkan tidak kecil jika dikaitkan dengan kondisi pemerintahan desa yang umumnya masih lemah. Diakui atau tidak, penyelenggaraan pemerintahan desa hingga saat ini masih memiliki banyak kelemahan dilihat dari kapasitas manajemen pemerintahan desa dan kompetensi kepala desa dan perangkat desa.

Tahun 2014 merupakan momentum kebangkitan penyelenggaraan pemerintahan desa menyusul disahka-nnya Undang-Undang No. 6 Tahun 2014 Tentang Desa. Melalui undang- undang tersebut Desa memperoleh kedudukan yang kuat dalam penyelenggaraan pemerin- tahan yang secara integral bagian dari penyelenggaraan pemerintahan nasional dan daerah.

Pada Umumnya setiap instansi pemerintah dalam kegiatan operasinya menggunakan berbagai sumber daya untuk mencapai tujuan yang telah ditetapkan terlebih dahulu. Bagaimana memanfaatkan salah satu sumber daya yang paling dominan yaitu sumber daya manusia, yang di butuhkan untuk mencapai tujuan yang direncanakan. Sumber daya manusia merupakan faktor penting dan utama dalam setiap organisasi,baik badan usaha pemerintah maupun swasta ataupun instansi.setiap pimpinan yang dalam hal ini adalah instansi pemerintahan tepatnya Kantor Kepala Desa Aek Korsik Kabupaten Labuhan Batu Utara mengharapkan kemampuan kerja,pencapaian prestasi maupun tingkat produktivitas yang tinggi dari masing-masing pegawai.

Karena itu peranan dan kedudukan Pegawai Negeri Sipil sangat menentukan dalam setiap organisasi. Karena merupakan tulang punggung pemerintah dalam proses penyelenggaraan pemerintah dalm melaksanakan Pembangunan Nasional.
Akan tetapi pada kenyataannya dalam penyelenggaraannya masih banyak mengalami kendala karena keterbatasan kemampuan yang tidak sesuai dengan tempat bekerjanya (Matondang, 2015)

Dalam peraturan pemerintah No 101 tahun 2000 tentang pendidikan dan pelatihan jabatan Aparatur Sipil Negara, di sebutkan bahwa dengan pelaksanaan pendidikan dan pelatihan, diharapkan dapat menciptakan sumber daya aparatur yang memiliki kompetensi yang diperlukan untuk meningkatkan mutu profesionalisme, sikap pengabdian, kesetian pada perjuangan bangsa dan negara, semangat persatuan dan kesatuan, dan pengembangan wawasan aparatur.

Manajemen Sumber Daya Manusia Menurut Hanry Simamora (2004) Manejemen sumber daya manusia adalah pendayagunaan ,pengembangan, penilaian, pemberian balas jasa, dan pengelolaan individu anggota organisasi atau kelompok karyawan, juga menyangkut desain dan implementasi sistem perencanaan,penyusunan karyawan, pengembangan karyawan, pengelolaan karir, evaluasi keinerja, kompensasi karyawan dan hubungan ketenagakenerjaan yang baik.

Menurut Adrew E.Sikula dalam Mangkunegara, (2015) pendidikan dan pelatihan merupakan proses pendidikan yang mempelajari pengetahuan konseptualdan teoritis yang ditujukan pada pegawai pelaksana untuk meningkatkan pengetahuan dan keterampilan untuk mencapai tujuan yang umum. Menurut PP No 1 Tahun 2000 tentang Diklat Jabatan Aparatur Sipil Negara, pendidikan dan pelatihan di defenisikan sebagai proses penyelenggaraan belajar mengajar dalam rangka meningkatkan Kinerja ASN.

Menurut Moekjijat adapun tujuan Dari pendidikan dan pelatihan antara lain: a) Untuk mengembangkan keahlian sehingga pekerjaan dapat di selesaikan dengan lebih efektif. b) Untuk menngembaangkan pengetahuan sehingga pekerjaan dapat diselesaikan secara lebih rasional; c) Pengembangan terhadap sikap, sehingga menimbulkan kemauan kerja sama dengan rekan- rekan pegawai dengan manajemen pemimimpin. 


\section{METODE PENELITIAN}

Metode yang dipakai dalam Penelitian ini ialah Metode Kualitatif yang berfokus kepada Pengembangan Kapasitas Aparatur Pemerintahan Desa. Menurut Sugiyono (2016:15) metode penelitian kualitatif adalah metode penelitian yang berlandaskan pada filsafat postpositivisme, digunakan untuk meneliti pada kondisi obyek yang alamiah peneliti adalah sebagai instrumen kunci.

Sifat pada penelitian ini adalah deskriptif. Menurut Sugiyono (2006: 11) metode deskriptif yaitu penelitian yang dilakukan untuk mengetahui nilai variabel mandiri, baik satu variabel atau lebih tanpa perbandingan, atau menghubungkan antara variabel satu dengan variabel yang lain.

$$
\text { Metode pengumpulan data }
$$

merupakan suatu cara untuk mendapatkan data yang diperlukan. Maka peneliti menggunakan metode pengumpulan data yaitu a) Kepustakaan: segala usaha yang dilakukan oleh peneliti untuk menghimpun informasi yang relevan dengan topik atau masalah yang akan sedang di teliti; b) informasi ini dapat di peroleh dari buku-buku ilmiah, karangan-karangan ilmiah, skripi, tesis, disertasi, peraturanperaturan dan sumber-sumber tertulis; c) Observasi: pengamatan dan pencatatan yang sistematis terhadap gejala -gejala yang di teliti.kegiatan pengamatan dan pencatatan di lakukan secara langsung pada objek penelitian; d) Wawancara: adalah pertemuan dua orang untuk bertukar informasi dan ide melalui tanya jawab, sehingga dapat dikonstruksikan makna dalam suatu topik tertentu; e) Dokumentasi: merupakan catatan peristiwa yang sudah berlalu. Dokumentasi biasanya berbentuk Tulisan, gambar atau karya-karya monumental dari seseorang.

Teknik analisis data yang di gunakan dalam penelitian ini adalah mengacu pada konsep Miles Huberman yaitu: a). Pengumpulan Data, merupakan upaya untuk mengumpulkan data dengan berbagai cara seperti: observasi, wawancara, dokumentasi dan sebagainya; b) Reduksi Data: merupakan kegiatan merangkum, memilih hal-hal pokok,memfokuskan pada hal-hal penting, dan mencari tema dan polanya; c) Penyajian Data: merupakan sebagai kumpulan informasi tersusun yang memberikan kemungkinan adanya penarikan kesimpulan atau pengambilan tindakan.pengambilan data ini membantu peneliti memahami peristiwa yang terjadi dan mengarah pada analisa atau tidakan lebih lanjut berdasarkan pemahaman.

\section{HASIL DAN PEMBAHASAN}

Kabupaten Labuhan Batu Utara Merupakan sebuah Kabupaten hasil Pemekaran dari Labuhan Batu terdiri dari Labuhan Batu Utara Labuhan Batu Induk dan Labuhan Batu Selatan. Kabupaten Labuhan Batu Utara Terletak di bagian tengah Provinsi Sumatera Utara pada 1ㅇ 58' - 20 50' Lintang Utara dan 99o 25'-100 05’ Bujur Timur dengan ketinggian 2.151 meter diatas permukaan laut.Luas Wilayah Kabupaten Labuhan Batu Utara adalah 3.545,80 $\mathrm{km}^{2}$, terdiri dari 8 (delapan) Kecamatan, 82 (delapan puluh dua) Desa dan 8 (delapan) kelurahan.

Demi terwujudnya pembangunan desa yang efektif dan efisien, tentunya di butuhkan sumber daya manusia terutama perangkat desa yang profesional. Dari segi pendidikan, pengetahuan, dan keterampilan sesuai dengan tugas yang di emban. Peningkatan kapaitas aparatur desa kini menjadi hal yang sangat penting demi memberikan kontribusi dalam pelaksanaan undang-undang desa. Peningkatan kapasitas aparatur desa di peroleh melalui pendidikan dan pelatihan yang di terima kepala desa maupun aparatur desa lainnya. Beberapa diantaranya yaitu pelatihan tentang aparatur desa, manajemen pemerintah desa, pelatihan pengembangan ekonomi, pelatihan Bimtek Kearsipan, dan pelatihan tata cara pemberdayaan usaha milik desa.

Karena pada hakikatnya pengembangan sumber daya manusia harus mempunyai tujuan yang berdasarkan kepentingan individu, organisasi dan kepentingan nasional. Pengembangan sumber daya manusia menghubungkan sumber daya manusia yang ada untuk kebutuhan pemerintah pada masa yang akan datang, untuk menghindari mismanajemen dan tumpang tindih dalam pelaksanaan tugas pokok.

Penyelenggaraan pemerintahan desa tidak terpisahkan dari penyelenggaraan otonomi daerah. Pemerintah desa merupakan 
unit terdepan dalam memberikan pelayanan terhadap masyarakat seta sebagai tombak untuk keberhasilan semua program yang di rencanakan. Oleh karena itu, upaya untuk meningkatkan kualitas sumber daya aparatur pemerintah desa dalam menjalankan tugas dan fungsi pemerintah desa.tentunya ini akan mewujudkan pemerintahan desa yang optimal.

Berdasarkan penelitian dapat kita lihat bahwa pendidikan dan pelatihan sangat di perlukan untuk membantu pemerintahan dalam penyelenggaraan tugas-tugas pemerintahan dan pembangunan secara berdaya guna dan berhasil guna dengan dukungan ASN yang profesional, bertanggung jawab, jujur, dan adil. sehingga pemerintah desa terus berupaya untuk memberikan kesejahteraan kepada seluruh masyarakat dan saling berkerja sama dalam membangun desa.

Pada dasar nya kinerja aparatur pemerintah desa, masih rendah terutama keahlian dari aparat pemerintah desa dalam hal memberikan pelayanan. Pelayanan yang berkualitas sering kali mengalami kesulitan untuk dapat dicapai karena pemerintah desa tidak selalu memahami bagaimana cara memberikan pelayan yang baik, hal ini disebabkan, masih rendahnya kemampuan aparatur pemerintah desa di lihat dari latar belakang pendidikan dan etos kerja sumber daya manusia.

Saat ini, yang menjadi tantangan utama di desa Aek Korsik ialah salah satunya adalah optimasi potensi dan peningkatan kapasitas sumber daya manusiasetempat yang masih minim.Hal ini tidak hanya tercermin dari sulitnya mencari figur-figur pemimpin desa yang visioner, berwawasan luas, dengan kapasitas yang mumpuni, melainkan juga problem yang kurang lebih sama terletak pada kelompok perangkat desa dengan kapasitas yang terbatas.

Pengembangan aparatur pemerintah desa di lakukan untuk menambah pengetahuan aparatur pemerintah desa dalam hal yang berkaitan dengan administrasi desa terutama dalam hal masalah desa. Karena setiap organisasi membutuhkan pengelolaan dan pengelolaan itu adalah aparatur desa tersebut.

Kapasitas pemerintah desa tentunya terkait dengan kemampuan pemerintahan desa dalam melaksanakan tugas dan fungsi tersebut di atas. Dalam konteks ini pengembangan kapasitas pemerintah desa idealnya sejalan dengan kewenangan yang diemban desa sebagaimana diamanatkan oleh UU Desa. Kapasitas pemerintah desa menjadi parameter penting bagi pencapain kinerja pemerintahan desa. Dengan kata lain, pencapaian kinerja pemerintahan desa yang baik hanya akan terwujud jika mendapat dukungan dari individu, organisasi dan sistem yang memadai. lemahnya kapasitas dan kinerja desa menyebabkan di butuhkannya pendidikan dan pelatihan berupa pendampingan, pemanfaatan jaringan, dan pembelajaran yang berkelanjutan terbukti mampu mendongkrak kapasitas dan kinerja desa dalam penyelenggaraan pemerintahan dan pembangunan desa.Sebagai contoh, pembuatan perencanaan desa dapat menjadi salah satu titik masuk untuk melihat kapasitas dan kinerja desa. Dalam konteks implementasi UU Desa, dokumen perencanaan (RPJMDes, APBDes, dan RKPDes) merupakan syarat pencairan Alokasi Dana Desa dari Kabupaten.

\section{SIMPULAN}

Sumber daya aparatur di pemerintahan desa masih belum memadai. Pendidikan dan pelatihan yang di dapat apatur pemerintah desa belum mampu di implementasikan di masyarakat karena keterbatasan sumber daya manusianya. Kurang nya peralatan yang menunjang kinerja para pegawai pemerintah desa. Upaya untuk lebih meningkatkan pengembangan kapasitas aparatur pemerintah desa di desa Aek Korsik Kecamatan Aek Kuo Kabupaten Labuhan Batu Utara. Pendidikan dan pelatihan bagi aparatur pemerintah desa perlu di tingkatkan terutama diklat teknis atau diklat fungsional. Sehingga alokasi dana untuk program diklat perlu ditingkatkan demi kepentingan aparatur pemerintah desa. Para aparatur desa lebih banyak diikut sertakan dalam acara hal yang berkaitan pengembangan kapasitas aparatur pemdes. Pemerintah Pusat harus memfasilitasi kebutuhan prasarana Desa Aek Korsik.

\section{DAFTAR PUSTAKA}

Husain, U. (2011). Metodologi Penelitian Sosial. Jakarta: Bumi Aksara

Mangkunegara, A.P. (2016) Perencanaan dan pengembangan Sumber Daya Manusia. Bandung PT Reflika Diatama.

Matondang, A., (2015). Pembinaan Aparatur Pemerintah dalam Pelaksanaan Tugas di 
Bagian Umum Sekretariatan Kantor Bupati, Jurnal Ilmu Pemerintahan dan Sosial Politik UMA,, 3 (2): 160-174.

Najib, M. (2015). Manajemen Pendidikan dan Pelatihan. Bandung: CV Pustaka Setia

Notoadmodjo, S. (2003). Pengembangan Sumber Daya Manusia.Jakarta: PT Rineka Cipta

Soedikjo, N. (2003) Pengembangan Sumber Daya Manusia. Jakarta: PT. Ranika Cipta.

Solekhan, M. (2014). Penyelenggaraan Pemerintahan Desa Berbasis Partisipasi Masyarakat.Malang: Setara Pass.

Sugiyono. (2006). Metode Penelitian Administrasi.Bandung: CV. Alfabeta Jakarta.

Sugiyono (2014). Metode Penelitian Administrasi dilengkapi Dengan Metode $R$ \& D. Bandung: Alfabeta
Sugiyono (2016). Metode Penelitian Pendidikan. Bandung: CV. Alfabeta Bandung

Thoha, M. (2005). Manajemen Kepegawain Sipil di Indonesia.Jakarta: Prenada Media UndangUndang

Undang-Undang No 23 Tahun 2014 Tentang Pemerintahan Daerah

Undang- Undang No. 6 Tahun 2014 Tentang Desa

Peraturan Pemerintah No. 72 Tahun 2005 Tentang Pemerintah Desa

Peraturan Pemerintah Republik Indonesia N0 43 Tahun 2014 Tentang Peraturan Pelaksanaan Undang- Undang No. 6 Tahun 2014 Tentang Desa

Undang-Undang No 5 Tahun 2014 Tentang Aparatur sipil Negara. 